American Journal of Pharmaceutical Education 2021; 85 (3) Article 7983.

\title{
RESEARCH
}

\section{Analysis of Research and Scholarship Criteria Within Promotion and Tenure Documents of US Pharmacy Schools}

\author{
Allen Snider, PharmD, ${ }^{\mathrm{a}}$ Kacey Hight, PharmD, ${ }^{\mathrm{b}}$ Allison Brunson, PharmD, ${ }^{\mathrm{c}}$ Nalin Payakachat, PhD, ${ }^{\mathrm{d}}$ \\ Amy M. Franks, PharmD ${ }^{\mathrm{d}, \mathrm{e}}$ \\ ${ }^{\text {a }}$ University of Kansas Health System, Kansas City, Kansas \\ ${ }^{\mathrm{b}}$ Ochsner LSU Health Shreveport, Shreveport, Louisiana \\ ${ }^{\mathrm{c}}$ Baptist Memorial Hospital-Memphis, Memphis, Tennessee \\ ${ }^{\mathrm{d}}$ University of Arkansas for Medical Sciences, College of Pharmacy, Little Rock, Arkansas \\ e Editorial Board Member, American Journal of Pharmaceutical Education, Arlington, Virginia
}

Submitted December 19, 2019; accepted November 25, 2020; published March 2021.

Objective. To describe criteria for evaluating faculty scholarship within the promotion and tenure guidance documents of US schools and colleges of pharmacy.

Methods. Promotion and tenure documents were obtained from the websites of US pharmacy schools or requested via electronic mail, and institutional characteristics were collected from publicly available online data. A qualitative content analysis was conducted to systematically catalogue document characteristics and criteria for promotion and tenure.

Results. Promotion and tenure guidance documents from 121 (85\%) of 142 pharmacy schools were analyzed. Institutions were 55\% public and equally distributed across Carnegie institutional classifications as well as geographic and extramural funding stratifications. Publications (94\%) and grants and contracts $(87 \%)$ were the most frequently included criteria for faculty advancement. More than $50 \%$ of schools recognized the criteria within promotion and tenure guidance documents but did not explicitly require faculty to achieve them before receiving promotion and/or tenure. For institutions that required publications for advancement, the most frequently required criterion was publication in peer-reviewed journals (47\%). Few schools (22\%) documented a specific number of required publications.

Conclusion. This analysis provides a comprehensive review of scholarship criteria in academic pharmacy promotion and tenure guidance documents. There was wide variability among scholarship criteria, and documents often lacked specific language defining scholarship requirements. As a result, faculty may find the documents less helpful for self-assessment and preparation toward promotion and/ or tenure. These benchmark data can assist pharmacy faculty and administrators in developing and revising promotion and tenure guidance documents to include clear criteria and better align with peer institutions.

Keywords: pharmacy, faculty, academic promotion, tenure, scholarship

\section{INTRODUCTION}

Together with teaching and service, scholarship is an essential component of the tripartite mission for all pharmacy faculty members. Scholarly achievements, such as pursuing and securing funding, presenting data, and publishing completed projects and innovations, are integral parts of faculty success. As faculty build upon these scholarly successes, along with accomplishments in teaching and service, they look for guidance from

Corresponding Author: Amy M. Franks, University of Arkansas for Medical Sciences, College of Pharmacy, 4301 W. Markham St., \#522, Little Rock, AR 72205. Tel: 501-2961296. Email: afranks@uams.edu institutional policies, mentors, and administrators about their readiness to seek promotion in academic rank and/or tenure. One of the most critical resources for both faculty and administrators to use in assessing faculty progress toward promotion and/or tenure is their school's promotion and tenure guidance documents. These documents are school-specific and may vary greatly in their requirements, clarity, specificity, and overall structure. ${ }^{1-3}$

To assist faculty in their pursuit of academic advancement, a clear, specific definition for all areas of scholarship is necessary within promotion and tenure guidance documents. ${ }^{4}$ The definition of scholarship has changed over the years from one focused on bench-based 


\section{American Journal of Pharmaceutical Education 2021; 85 (3) Article 7983.}

research to that of Boyer's expanded definition, which includes four areas of scholarship: discovery, integration, application, and teaching. ${ }^{5}$ Existing data on scholarship requirements within promotion and tenure documents are scarce and were published more than a decade ago. ${ }^{6-8}$ Since then, the number of pharmacy schools in the United States has greatly increased, leading to subsequent expansion in the number of pharmacy faculty. Further, the educational and training backgrounds of pharmacy faculty have become more diverse, with a shift toward more clinical faculty positions in academic pharmacy. ${ }^{6}$ These positions often add responsibility for maintaining a clinical practice in addition to the more traditional faculty roles of scholarship, teaching, and service. Nutescu and colleagues previously reported that clinical faculty were expected to spend an average of $11.7 \%$ of their time on scholarship and/or research, whereas $51.2 \%$ of time was intended for clinical practice and clinical teaching. ${ }^{9}$ In preparation for these roles, more faculty are now clinically trained, having completed a PharmD degree program and one to two years of residency training, than in previous years when the academy primarily included faculty with $\mathrm{PhD}$ or other graduate degrees. ${ }^{10}$ Accordingly, the scholarly publishing productivity of different types of faculty ranged from 0.82 to 2.2 publications per faculty per year as assessed by several studies between 2011 and 2017. ${ }^{11-14}$ These trends raise questions about how differing faculty backgrounds and position responsibilities might influence promotion and tenure scholarship requirements at schools and colleges of pharmacy.

Considering the major changes to the demographics of pharmacy faculty over the previous decades, it is important to examine scholarship requirements for promotion and tenure in US pharmacy schools. Similarly, promotion guidelines developed by the Society of General Internal Medicine highlight the need to recognize scholarship in addition to clinical practice activities performed by physician clinician-educators. ${ }^{15}$ The guidelines advocate for clear, specific criteria for promotion that are consistent with the primary expectations of faculty positions. However, although clinician-educators spend substantial time in clinical teaching and practice, the evaluation of scholarly contributions is critical in the advancement of all faculty. ${ }^{15}$ This balanced approach to promotion applies to pharmacy practice as well. According to their 2016 Standards, the Accreditation Council for Pharmacy Education (ACPE) requires that schools and colleges of pharmacy "develop mechanisms to assess both the quantity and quality of faculty scholarly productivity." "16 The scholarship requirements outlined in guidance documents for promotion and tenure, both in general and as they apply to clinical, teaching, and other specific types of faculty appointments, should provide direct guidance to faculty in their pursuit of promotion and tenure. This clarity of expectations also benefits institutions by facilitating optimal productivity and achievement from their faculty members. ${ }^{1}$

To date, no broad-scale characterization and analysis of the content of promotion and tenure guidelines has been published. The purpose of this study was to examine the scholarship requirements for promotion and/or tenure in US academic pharmacy institutions. These data were collected to better understand current requirements and guidance provided for faculty seeking promotion and tenure and compare these requirements across different institutional characteristics. In addition, data generated from this study provide a benchmark for consideration by schools and colleges of pharmacy when evaluating, revising, or creating their own promotion and tenure guidance documents. These national-level benchmark data can also provide valuable information regarding the promotion and tenure requirements of peer institutions.

\section{METHODS}

A list of all US-based schools and colleges of pharmacy was retrieved from the 2018 member institutions list on the American Association of Colleges of Pharmacy (AACP) website, including those with ACPE pre-candidate, candidate, and accredited status. ${ }^{17}$ Promotion and tenure guidance documents were obtained by searching the website of each school. When documents were not available online or required login credentials for access, email requests were sent to a faculty contact at the institution. If the obtained promotion and tenure guidance documents referred to more specific policies (eg, department/unit criteria or supplementary materials), these additional policies were requested via email to a faculty contact at that institution. All emailed requests were repeated once if the first request did not receive a response. In all correspondence, investigators assured confidentiality of materials and reporting of data in aggregate form only. Promotion and tenure guidance documents were collected between October 2017 and July 2018. When multiple separate but relevant promotion and tenure guidance documents for a single institution were obtained, they were merged into a single document file for that institution. Promotion and tenure guidance documents were housed within a qualitative analysis software program, MAXQDA, version 12 (VERBI GmbH).

Institutional characteristics were collected for each school and college from the most recent online data available, including number of students enrolled for most recently reported class, ${ }^{18}$ public or private status, ${ }^{19}$ 2017 funding rank for all extramural grants,${ }^{20}$ number of 


\section{American Journal of Pharmaceutical Education 2021; 85 (3) Article 7983.}

full-time pharmacy faculty during $2017,{ }^{17}$ ACPE accreditation status, ${ }^{21}$ geographic region according to the National Association of Boards of Pharmacy (NABP) district, ${ }^{22}$ and the 2018 Carnegie Classifications. ${ }^{23}$ Institutional data were housed in an Excel spreadsheet and linked to promotion and tenure guidance documents within MAXQDA using unique institutional identifier numbers.

\section{Qualitative Content Analysis}

Using MAXQDA software and methods consistent with best practices in qualitative research and systematic reviews, ${ }^{24,25}$ we conducted a qualitative content analysis of all available promotion and tenure guidance documents. A coding scheme was developed by the research team to characterize each document and capture specific information within documents. The initial coding scheme included codes describing quantitative and qualitative criteria by which faculty scholarship would be reviewed for promotion and/or tenure, such as publications, presentations, funding, and honors and awards. Three descriptor categories (Table 1) were used to further characterize scholarship criteria within the documents: level of requirement (required vs not required but credit given); purpose of review (for promotion, tenure, or no distinction between promotion and tenure); and type of evidence in criteria (quantitative vs qualitative). Additionally, the frequency of the inclusion of the scholarship of teaching and learning (SOTL) was evaluated because of the traditionally lesser acceptance of this type of scholarship, the growing interest in it among pharmacy educators, and the repeated calls for defining its value within promotion and tenure criteria. ${ }^{26-29}$

The initial coding scheme was independently tested by the authors and subsequently refined by the research team using an iterative process. Once the coding scheme was finalized, documents were randomly assigned for coding by one of the authors, and each document was coded in MAXQDA (coding scheme available upon request from the corresponding author). When coders had questions about how to apply the coding scheme to particular content within a document, they sought the consensus of the full coding group to ensure accuracy and reproducibility of coding. An additional author periodically reviewed the codes and settled discrepancies in coding definitions among coders. ${ }^{24}$ Descriptive statistics were reported for general characteristics of the documents, institutional characteristics, and scholarship criteria for promotion and tenure. The investigators' university institutional review board determined this study was not human subject research.

\section{RESULTS}

Promotion and tenure guidance documents were obtained from 123 (87\%) of 142 US schools and colleges

Table 1. Key Descriptors of Scholarship Criteria Described in the Promotion and Tenure Guidance Documents of US Schools and Colleges of Pharmacy

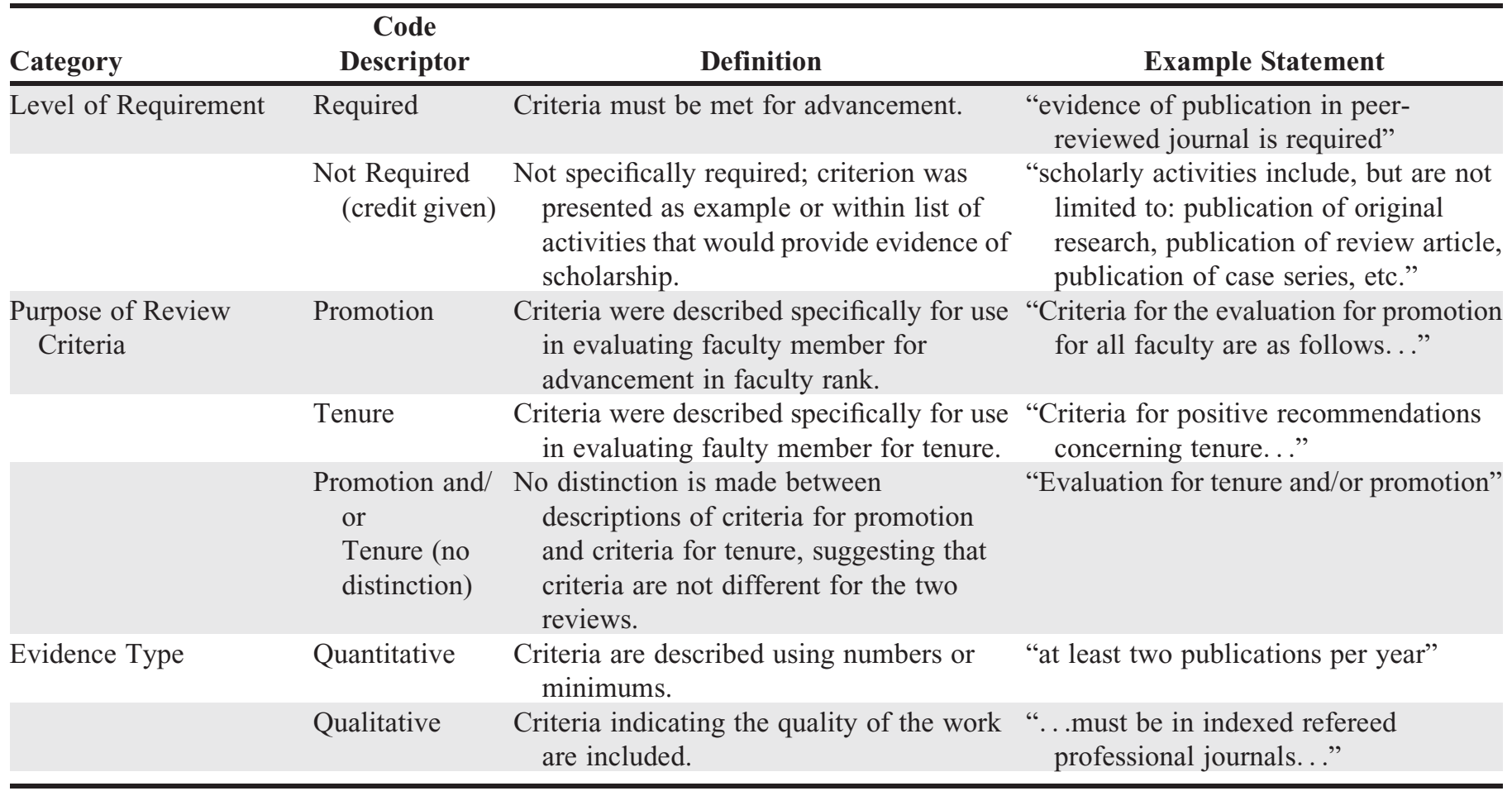




\section{American Journal of Pharmaceutical Education 2021; 85 (3) Article 7983.}

of pharmacy with AACP institutional membership. Documents were not obtained from the remaining 19 institutions for the following reasons: the document was under revision or not yet developed $(n=6)$, no response was received from the institution after two requests $(\mathrm{n}=10)$, and the institution declined to send the document $(n=3)$. The documents received from two schools had to be excluded from the analysis because not enough information was included $(\mathrm{n}=1)$ and the document was not in English $(\mathrm{n}=1)$. The remaining promotion and tenure guidance documents from 121 (85\%) schools were included in the analyses. The institutional characteristics of the schools are presented in Table 2. The median student enrollment of the institutions was 102.5 students, and the median number of faculty at each institution was 45. Fifty-five of the institutions were public, 33\% were Carnegie Classification R1 (very high research activity), 39\% received extramural funding between $\$ 0-\$ 1$ million, and $26 \%$ received extramural funding $>\$ 10$ million.

\section{Qualitative Content Analysis}

Scholarship was frequently included as a component of promotion and tenure guidance documents (Figure 1). The most frequently included scholarship criteria were related to publications $(94.2 \%)$ and grants $(86.8 \%)$. The least frequently included criterion was SOTL (40.5\%). Scholarship criteria was designated as not required for promotion and tenure by more than $50 \%$ of schools; however, all schools took a faculty member's achievement of these criteria into consideration in the promotion and tenure evaluation (ie, credit was given).

Table 2. Institutional Characteristics of US Schools and Colleges of Pharmacy Included in an Analysis of Promotion and Tenure Guidance Documents

\begin{tabular}{|c|c|c|c|}
\hline \multirow[b]{2}{*}{ Characteristic } & \multicolumn{3}{|c|}{$\begin{array}{r}\text { Colleges or Schools Reporting } \\
\end{array}$} \\
\hline & No. $(\%)$ or Mean (SD) $\mathrm{N}=121$ & Median & Range \\
\hline Student enrollment per college/school ${ }^{\mathrm{a}}$ & $115.6(56.9)$ & 102.5 & $35-340$ \\
\hline \multicolumn{4}{|l|}{ Institution Type } \\
\hline Public & $67(55.4)$ & & \\
\hline Private & $54(44.6)$ & $\mathrm{n} / \mathrm{a}$ & $\mathrm{n} / \mathrm{a}$ \\
\hline $\begin{array}{l}\text { Doctoral universities, very high research } \\
\text { activity (R1) }\end{array}$ & $40(33.1)$ & & \\
\hline $\begin{array}{l}\text { Doctoral universities, high research activity } \\
\text { (R2) }\end{array}$ & $19(15.7)$ & & \\
\hline Doctoral/professional universities & $27(22.3)$ & & \\
\hline Other & $35(28.9)$ & $\mathrm{n} / \mathrm{a}$ & $\mathrm{n} / \mathrm{a}$ \\
\hline$\geq \$ 10 \mathrm{M}$ & $23(19.0)$ & & \\
\hline No data & $34(28.1)$ & $\$ 2.5 \mathrm{M}$ & $\$ 0-64 M$ \\
\hline \multicolumn{4}{|l|}{ Accreditation Status } \\
\hline \# Accredited & $113(93.4)$ & & \\
\hline \# Candidate & $5(4.1)$ & & \\
\hline \# Pre-candidate & $3(2.5)$ & $\mathrm{n} / \mathrm{a}$ & $\mathrm{n} / \mathrm{a}$ \\
\hline \multicolumn{4}{|l|}{ Geographic locations by NABP district } \\
\hline District 1 & $8(6.6)$ & & \\
\hline District 2 & $21(17.4)$ & & \\
\hline District 3 & $23(19.0)$ & & \\
\hline
\end{tabular}

$\mathrm{SD}=$ standard deviation

${ }^{a}$ The most recently available enrollment numbers as reported by the college/schoool ${ }^{18}$ 


\section{American Journal of Pharmaceutical Education 2021; 85 (3) Article 7983.}

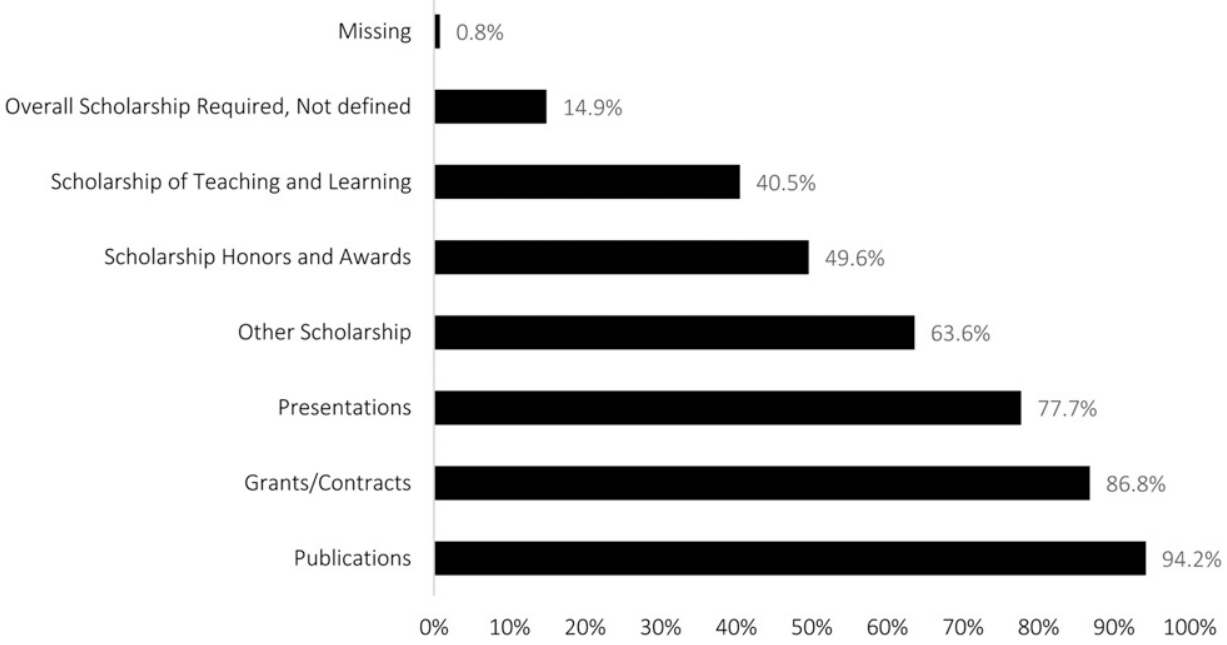

Figure 1. Frequency of Scholarship Criteria Included in Promotion and Tenure Guidance Documents

The number of papers a faculty had published was the most common quantitative requirement $(21.5 \%)$. There was variation among documents regarding the minimum required publications specified, with some schools quantifying the cumulative number of all publications at the time of promotion and tenure evaluation, and others specifying cumulative numbers for first, senior, and/or corresponding author publications. Although difficult to reduce these requirements to standard nomenclature and timeframes, we attempted to do so in a post-hoc analysis using the numbers from the small group of schools that provided their quantitative requirements. In this analysis, we assumed a six-year timeframe for promotion and/or tenure (eg, a requirement of one publication per year multiplied by six years would result in a requirement of six cumulative publications). Using the minimum requirements reported within the promotion and tenure guidance documents, medians of 3.5 cumulative publications (range 2-12) were required during the six-year evaluation period for promotion, 7.5 cumulative publications (range 3-10) were required during the sixyear evaluation period for tenure, and 5 cumulative publications (range 1-15) were required during the six-year evaluation period when there was no distinction between promotion and/or tenure in the document. For first, senior, or corresponding author publications, a median of $2 \mathrm{cu}-$ mulative publications (range 1-3) were required for promotion, 3 cumulative publications (range 3-4) were required for tenure, and 5 cumulative publications (range 3-6) were required when there was no distinction between promotion and/or tenure.

The most commonly required qualitative criteria related to publications was publication in peer-reviewed literature $(47.1 \%)$. Other qualitative requirements for publishing included authorship criteria (18.2\%) and publication of original research (18.2\%). Qualitative requirements for other areas of scholarship (eg, presentations, grants, etc) were infrequent. The majority of institutions either designated these achievements as not required (credit given) or did not include them in their promotion and tenure guidance document at all. Frequencies of specific criteria in the promotion and tenure guidance documents are shown according to Carnegie classification in Table 3. We did not observe broad-scale trends indicating differences between different classifications of institutions.

Promotion and tenure guidance documents infrequently differentiated specific scholarship criteria for the evaluation of tenure vs promotion in academic rank. There were few explicit statements of scholarship criteria needed for tenure, with less than $20 \%$ of documents including them (Figure 2). More often, schools did not differentiate between promotion and tenure in descriptions of required or recognized achievements.

\section{DISCUSSION}

We present the first comprehensive qualitative content analysis of the scholarship criteria within promotion and tenure guidance documents from US schools and colleges of pharmacy. We found wide variability among the documents, and specific requirements or recommendations to assist in faculty self-assessment were often lacking. Although the majority of institutions included scholarship criteria related to publications (94\%), grants or contracts $(87 \%)$, and presentations $(78 \%)$, less than half included any quantitative or qualitative requirements for these criteria. Of those that included a specifically defined requirement, publication in a peer-reviewed 
American Journal of Pharmaceutical Education 2021; 85 (3) Article 7983.

Table 3. Scholarship Criteria Requirements of US Schools and Colleges of Pharmacy ${ }^{\mathrm{a}}$

\begin{tabular}{|c|c|c|c|c|c|}
\hline & $\begin{array}{l}\text { Total No. }(\%) \\
(\mathrm{N}=121)\end{array}$ & $\begin{array}{l}\text { R1 No. (\%) } \\
(\mathrm{N}=40)\end{array}$ & $\begin{array}{l}\text { R2 No. (\%) } \\
(\mathrm{N}=19)\end{array}$ & $\begin{array}{l}\text { D/PU No. (\%) } \\
(\mathbf{N}=\mathbf{2 7})\end{array}$ & $\begin{array}{c}\text { Other No. }(\%) \\
(\mathrm{N}=35)\end{array}$ \\
\hline \multicolumn{6}{|l|}{ Publications } \\
\hline \multicolumn{6}{|l|}{$\begin{array}{l}\text { Required Quantitative Criteria for } \\
\text { Publications }\end{array}$} \\
\hline Number of total publications & $26(21.5)$ & $9(22.5)$ & $6(32.6)$ & $4(14.8)$ & $7(20.0)$ \\
\hline $\begin{array}{l}\text { Number of total first/senior } \\
\text { authorship }\end{array}$ & $12(9.9)$ & $4(10.0)$ & $5(26.3)$ & $2(7.4)$ & $1(2.9)$ \\
\hline $\begin{array}{l}\text { Other quantitative criteria for } \\
\text { publications }\end{array}$ & $4(3.3)$ & $1(2.5)$ & $1(5.3)$ & 0 & $2(5.7)$ \\
\hline \multicolumn{6}{|l|}{$\begin{array}{l}\text { Required Qualitative Criteria for } \\
\text { Publications }\end{array}$} \\
\hline $\begin{array}{l}\text { Authorship criteria (eg, first } \\
\text { author) }\end{array}$ & $22(18.2)$ & $8(20.0)$ & $4(21.1)$ & $3(11.1)$ & $7(20.0)$ \\
\hline Citation metrics & $8(6.6)$ & $5(12.5)$ & $1(5.3)$ & 0 & $2(5.7)$ \\
\hline Peer-reviewed/refereed journal & $57(47.1)$ & $22(55.0)$ & $9(47.4)$ & $9(33.3)$ & $17(48.6)$ \\
\hline Original research & $22(18.2)$ & $11(27.5)$ & $3(15.8)$ & $1(3.7)$ & $7(20.0)$ \\
\hline Book/book chapter & $3(2.5)$ & 0 & 0 & $1(3.7)$ & $2(5.7)$ \\
\hline $\begin{array}{l}\text { Specific publication types were } \\
\text { weighted according to } \\
\text { importance }\end{array}$ & $8(6.6)$ & $2(5.0)$ & 0 & $1(3.7)$ & $5(14.3)$ \\
\hline $\begin{array}{l}\text { Publication Required but Specific } \\
\text { Criteria Not Defined }\end{array}$ & $18(14.9)$ & $9(22.5)$ & $3(15.8)$ & $3(11.1)$ & $3(8.6)$ \\
\hline $\begin{array}{l}\text { Publication Not Required, but Credit } \\
\text { Given }\end{array}$ & 77 (63.6) & $25(62.5)$ & $12(63.2)$ & $20(74.1)$ & $20(57.1)$ \\
\hline \multicolumn{6}{|l|}{ Presentations } \\
\hline \multicolumn{6}{|l|}{$\begin{array}{l}\text { Required Quantitative Criteria for } \\
\text { Presentations }\end{array}$} \\
\hline Number of total presentations & $9(7.4)$ & $2(5.0)$ & $3(15.8)$ & $2(7.4)$ & $2(5.7)$ \\
\hline $\begin{array}{l}\text { Number of specific types of } \\
\text { presentation }\end{array}$ & $2(1.7)$ & 0 & 0 & $1(3.7)$ & $1(2.9)$ \\
\hline $\begin{array}{l}\text { Other quantitative criteria for } \\
\text { presentations }\end{array}$ & $2(1.7)$ & 0 & 0 & 0 & $2(5.7)$ \\
\hline \multicolumn{6}{|l|}{$\begin{array}{l}\text { Required Qualitative Criteria for } \\
\text { Presentations }\end{array}$} \\
\hline $\begin{array}{l}\text { Presentation type was specified or } \\
\text { weighted }\end{array}$ & $11(9.1)$ & $4(10.0)$ & $1(5.3)$ & $3(11.1)$ & $3(8.6)$ \\
\hline $\begin{array}{l}\text { Meeting type for presentation was } \\
\text { specified or weighted }\end{array}$ & $8(6.6)$ & $6(15.0)$ & 0 & $1(3.7)$ & $1(2.9)$ \\
\hline $\begin{array}{l}\text { Other qualitative criteria for } \\
\text { presentations }\end{array}$ & $8(6.6)$ & $3(7.5)$ & $1(5.3)$ & 0 & $4(11.4)$ \\
\hline $\begin{array}{l}\text { Presentations Required, but Specific } \\
\text { Criteria Not Defined }\end{array}$ & $16(13.2)$ & $6(15.0)$ & $2(10.5)$ & $4(14.8)$ & $4(11.4)$ \\
\hline $\begin{array}{l}\text { Presentation Not Required, but } \\
\text { Credit Given }\end{array}$ & $71(58.7)$ & $19(47.5)$ & $14(73.7)$ & $16(59.3)$ & 22 (62.9) \\
\hline
\end{tabular}

\section{Grants/Contracts}

Required Quantitative Criteria for

Grants

\begin{tabular}{lllccc}
$\begin{array}{c}\text { Number of funded grants and/or } \\
\text { amount of grant funding }\end{array}$ & $6(5.0)$ & $4(10.0)$ & $1(5.3)$ & $1(3.7)$ & 0 \\
$\begin{array}{c}\text { Number of reviewed/scored } \\
\text { grants }\end{array}$ & 0 & 0 & 0 & 0 & 0 \\
Number of submitted grants & $3(2.5)$ & 0 & $1(5.3)$ & 0 & $2(5.7)$ \\
\hline & & & & (Continued)
\end{tabular}


American Journal of Pharmaceutical Education 2021; 85 (3) Article 7983.

Table 3. (Continued)

\begin{tabular}{|c|c|c|c|c|c|}
\hline & $\begin{array}{l}\text { Total No. }(\%) \\
\qquad(\mathrm{N}=121)\end{array}$ & $\begin{array}{l}\text { R1 No. }(\%) \\
\quad(\mathrm{N}=40)\end{array}$ & $\begin{array}{l}\text { R2 No. }(\%) \\
(\mathrm{N}=19)\end{array}$ & $\begin{array}{l}\text { D/PU No. }(\%) \\
(\mathrm{N}=\mathbf{2 7})\end{array}$ & $\begin{array}{l}\text { Other No. }(\%) \\
\qquad(\mathrm{N}=35)\end{array}$ \\
\hline \multicolumn{6}{|l|}{$\begin{array}{l}\text { Required Qualitative Criteria for } \\
\text { Grants }\end{array}$} \\
\hline Grant sources specified/weighted & $7(5.8)$ & $5(12.5)$ & 0 & $1(3.7)$ & $1(2.9)$ \\
\hline Extramural funding & $35(28.9)$ & $16(40.0)$ & $6(31.6)$ & $4(14.8)$ & $9(25.7)$ \\
\hline $\begin{array}{l}\text { Investigator role specified/ } \\
\text { weighted (eg, principal } \\
\text { investigator) }\end{array}$ & $24(19.8)$ & $9(22.5)$ & $1(5.3)$ & $4(14.8)$ & $10(28.6)$ \\
\hline $\begin{array}{l}\text { Other qualitative criteria for } \\
\text { grants }\end{array}$ & $9(7.4)$ & $4(10.0)$ & $1(5.3)$ & $1(3.7)$ & $3(8.6)$ \\
\hline $\begin{array}{l}\text { Grants Required, but Specific } \\
\text { Criteria Not Defined }\end{array}$ & $12(9.9)$ & $6(15.0)$ & $1(5.3)$ & $1(3.7)$ & $4(11.4)$ \\
\hline $\begin{array}{l}\text { Grants Not Required, but Credit } \\
\text { Given }\end{array}$ & $72(59.5)$ & $21(52.5)$ & $13(68.4)$ & $17(63.0)$ & $21(60.0)$ \\
\hline $\begin{array}{l}\text { Required Qualitative Criteria for } \\
\text { Scholarship Honors/Awards }\end{array}$ & $5(4.1)$ & $2(5.0)$ & 0 & $1(3.7)$ & $2(5.7)$ \\
\hline $\begin{array}{l}\text { Scholarship Honors/Awards } \\
\text { Required, but Specific Criteria } \\
\text { Not Defined }\end{array}$ & $4(3.3)$ & $3(7.5)$ & 0 & 0 & $1(2.9)$ \\
\hline $\begin{array}{l}\text { Scholarship Honors/Awards Not } \\
\text { Required, but Credit Given } \\
\text { Other Evidence of Scholarship }\end{array}$ & $53(43.8)$ & $17(42.5)$ & $12(63.2)$ & $14(51.9)$ & $10(28.6)$ \\
\hline $\begin{array}{l}\text { Required Quantitative Criteria for } \\
\text { Other Evidence of Scholarship }\end{array}$ & 0 & 0 & 0 & 0 & 0 \\
\hline $\begin{array}{l}\text { Scholarship of Teaching and } \\
\text { Learning }\end{array}$ & & & & & \\
\hline Quantitative required & 0 & 0 & 0 & 0 & 0 \\
\hline Qualitative required & $5(4.1)$ & $4(10.0)$ & 0 & 0 & $1(2.9)$ \\
\hline Required, not defined & $1(0.8)$ & $1(2.5)$ & 0 & 0 & 0 \\
\hline Not required, credit given & $47(38.8)$ & $15(37.5)$ & 6 & $17(31.6)$ & $9(25.7)$ \\
\hline
\end{tabular}

Abbreviations: R1=doctoral universities, very high research activity; R2=doctoral universities, high research activity; $\mathrm{D} / \mathrm{PU}=$ doctoral/professional universities

${ }^{a}$ According to institution type as based on Carnegie Classification. ${ }^{23}$

journal was the one most cited. The most common quantitative criterion was the number of total publications, but only $22 \%$ of institutions included this requirement.

Faculty have long recognized the importance of scholarship in fulfilling their institutional commitment. When asked in 1995 what was perceived as the most important factors when evaluated for promotion and tenure, scholarly activities such as publications, extramural funding, and scholarly presentations ranked above criteria involving service or teaching. ${ }^{8}$ Similarly, excellence in scholarship was found to be the area of highest priority for promotion among pharmacy faculty in 2006 . $^{7}$ In spite of these observations, faculty have expressed dissatisfaction with the perceived disconnect between expectations necessary for promotion and tenure and the 


\section{American Journal of Pharmaceutical Education 2021; 85 (3) Article 7983.}

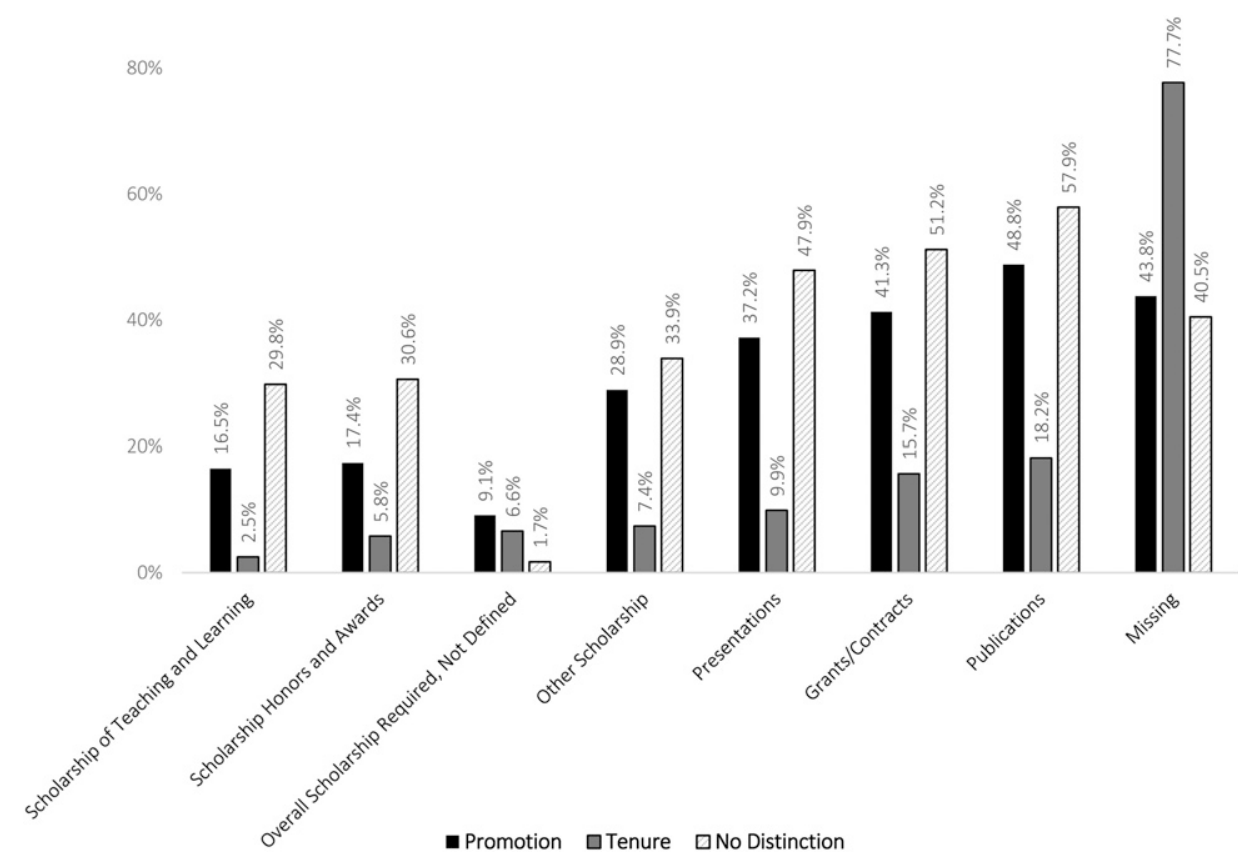

Figure 2. Frequency of Scholarship Criteria Within Promotion and Tenure Guidance Documents, Specific to Promotion, Tenure, and Promotion and/or Tenure Without Distinction

actual time and effort spent on these responsibilities during their daily work. ${ }^{30}$ In the most recent AACP Faculty Survey, the majority (61.2\%) of faculty reported that the amount of time spent on research was appropriate, but almost one-third $(31.5 \%)$ reported that too little time was spent on research relative to other responsibilities. ${ }^{31}$ Nonetheless, approximately $80 \%$ of faculty agreed that their institution's performance assessment criteria were consistent with their faculty responsibilities and that the criteria were explicit and clear, and $73.8 \%$ agreed that their institution's promotion and tenure policies and procedures were consistently applied. ${ }^{31}$ However, Robles and colleagues touched on a troublesome finding that $60 \%$ of surveyed pharmacy practice faculty recognized scholarship was required for advancement by their institutions, but only $32 \%$ of faculty thought scholarship should be required for advancement in academic pharmacy. ${ }^{32}$ Forty-one percent of this group felt that scholarship was overemphasized. ${ }^{32}$ Together, these observations underscore the importance of better understanding of the norms related to scholarship and career advancement across the discipline. Clarifying how scholarship is evaluated throughout US pharmacy schools may help to further evolve the promotion and tenure process and gain buy-in from faculty who can use the current data to benchmark expectations from one institution to another.

Excellence in scholarship is often stated as a requirement for promotion and tenure, yet what defines excellence is rarely clearly identified. ${ }^{30,33}$ Further, institutional expectations for promotion and tenure have evolved from an expectation of excellence in at least one of the three traditional faculty responsibilities (teaching, scholarship, and service) to a greater emphasis being placed on achieving excellence specifically in scholarship or in all three areas. ${ }^{30}$ This finding is similar to the evaluation of promotion and tenure guidance documents in a small sample of pharmacy schools conducted by Klein and colleagues. ${ }^{2}$ Although limited to the 10 institutions near the University of Michigan, their analysis found that seven schools required excellence in scholarship but they were unable to identify a common definition of excellence within the documents reviewed. Like in our evaluation, the institutions were more likely to provide examples of how a faculty could support their track record than to provide specific quantitative and qualitative requirements to faculty seeking promotion and tenure. ${ }^{2}$ The most common specific criterion included in the promotion and tenure guidance documents included in our evaluation was the requirement for publication in peer-reviewed journals. In general, differentiating between published works that are peerreviewed and those that are not peer-reviewed is not debated among academics, with higher value placed on the former. ${ }^{30}$ Schimanski and Alperin previously identified this distinction as one method to evaluate the quality of published works in promotion and tenure reviews. ${ }^{30}$ 


\section{American Journal of Pharmaceutical Education 2021; 85 (3) Article 7983.}

The relative importance of scholarship criteria in promotion and tenure decisions varies substantially among health sciences disciplines. In contrast to academic pharmacy, deans from nursing and allied health programs placed higher value on teaching effectiveness for tenure decision, with only $22 \%$ of allied health and $19 \%$ of nursing deans placing the highest value on research. ${ }^{34}$ However, many of these deans $(84 \%$ of allied health deans and $41 \%$ of nursing deans) also strongly agreed or agreed that it would be difficult for a faculty member to achieve tenure without publishing in refereed journals. ${ }^{35}$ Most disagreed or strongly disagreed that publications should just be counted and not qualitatively evaluated (66\% allied health deans and 55\% nursing deans). The majority felt that the number of publications, research grants, and professional meeting presentations were very important or fairly important to tenure decisions. ${ }^{35}$ In academic medicine, Jhala and colleagues reviewed a sample of the promotion and tenure guidance documents of 30 institutions for criteria considered in the promotion of radiology faculty in clinical educator tracks. ${ }^{36}$ Like with the current analysis, they found a high variability of criteria across schools, with documented criteria for meeting presentations $(73 \%)$, book chapters $(63 \%)$, peer-reviewed publications $(57 \%)$, quality of publication (43\%), first author publications (27\%), and specified number of publications $(7 \%)$. The authors noted that the quality of publications was more likely to be included as a criterion than quantity of publications, with qualifiers such as peer reviewed and author order. However, none of the $43 \%$ of institutions including quality of publications as a criterion provided information on how quality was defined. ${ }^{36}$

Literature has shown that unclear promotion policies can lead to unrealistic expectations and perceived unfairness among employees, which can then result in negative work outcomes, such as low job satisfaction, increased turnover, and poor organization commitment. ${ }^{1,37-46}$ Therefore, we believe that clear objective measures and transparency in promotion and tenure guidance documents can improve faculty members' perceptions of procedural justice, thus resulting in more positive outcomes such as satisfaction with faculty position and career, and a high level of organizational commitment among faculty members. ${ }^{1,37-39,42,45}$ This in turn builds clear expectations for faculty and may also prevent optimism bias toward the promotion and tenure process. Although a balance between explicitly defined criteria for promotion and tenure and more flexible holistic guidelines that allow faculty more leeway in making their own individualized case for promotion and tenure may seem ideal, Hardre and Kollman argue that many promotion and tenure guidance documents are "largely amotivating" in part because of their lack of specific guidance. ${ }^{1}$ Among their recommendations is for institutions to use clear, precise language that helps faculty align their individual performance plans with evaluative criteria. In simple terms, this allows faculty to know what to do to succeed in their career advancement while being able to set their own personally meaningful pathway to achieve these criteria. Further, they call for the establishment of objective and valid standards focusing on merit, competence, and achievement that allow faculty to self-monitor their performance. Promotion and tenure guidance documents often include vague direction for achievement such as "high quality research," which may lead to uncertainty among faculty members seeking advancement and inconsistency in the administration's evaluation of those candidates. ${ }^{1}$ However, the authors warn that such specificity in criteria can also affect motivation by focusing too much on quantitative or qualitative factors, eg, specific language for the number of publications may result in a faculty member sacrificing quality of work to achieve the numerical criterion rather than focusing on higher quality work but having fewer publications. ${ }^{1}$

In our analysis, we found that promotion and tenure guidance documents often omitted information specific to tenure requirements. This is problematic if the expectations for tenure are not clearly defined. Although more investigation is needed to better understand this trend, we suggest that explicit requirements for tenure may not be included because, for faculty in tenure-track positions, promotion and tenure criteria may be synonymous. Even when two separate votes are required when making promotion and tenure decisions, our evaluation shows that promotion and tenure committees often do not have separate written criteria in place to evaluate the decisions individually. The absence of clear delineation between the evaluation criteria for promotion and that for tenure decisions may suggest that differences may arise from anecdotal and/or oral history or tradition within the institution. When these differences, if they exist, are not described in writing within promotion and tenure guidance documents, it puts the faculty member at risk of being unaware of, misunderstanding, or wrongly applying these separate evaluation criteria to their own record of accomplishments, ultimately putting them at a disadvantage for career advancement. ${ }^{1}$ In our experience, tenure-track and nontenure-track faculty appointments frequently differ in the distribution of faculty effort among the core responsibilities of scholarship, teaching, and service. If faculty have a clear understanding of their assigned distribution of effort and the achievements needed for a favorable promotion and tenure review (eg, 


\section{American Journal of Pharmaceutical Education 2021; 85 (3) Article 7983.}

excellence in scholarship may be required for tenuretrack faculty), they can develop a plan to achieve what is needed. This should be explored in future work to determine whether tenure track faculty have a clear understanding of the expectations for tenure or if more clearly defined requirements for achieving tenure should be included in promotion and tenure guidance documents.

Based on the results of our analysis, we believe pharmacy schools should review their promotion and tenure guidance documents, with a focus on achieving a higher level of transparency and specificity by which their faculty can reliably self-assess progress toward academic promotion. Schools should assess their own processes to identify the unwritten requirements and expectations for promotion and tenure that need to be defined in their written documents. Data from our analysis can be used to initiate this review, as findings from the current analysis provide a comprehensive, contemporary picture of scholarship criteria among US pharmacy schools and can act as a benchmarking mechanism. Faculty and administrators can use these data to determine how well their institution reflects national trends and identify areas in which to provide more detail on expectations. The scholarship criteria in Table 3 can be used to systematically compare the institution's priorities with the criteria included in their promotion and tenure guidance documents. At minimum, we recommend developing specific quantitative and qualitative criteria for those areas of scholarship most frequently included in our sample of promotion and tenure guidance documents (eg, publications, grants or contracts, presentations, etc). Institutions could elect to use our system of descriptors to further enhance the clarity of their criteria, noting the level of requirement (required vs not required [credit given]) and the type of evidence reviewed (quantitative vs qualitative). We also believe it is imperative to clearly identify when criteria apply to decisions for promotion only, tenure only, or both promotion and tenure. We recommend that non-administrative faculty in all stages of their career participate in this process as their perspectives can help uncover existing gaps in their institution's promotion and tenure guidance documents.

Although our data represent the most comprehensive and up-to-date analysis of promotion and tenure guidance documents from US pharmacy schools, we recognize the limitations of our analysis. We carefully analyzed the content of each institution's document(s), but as external reviewers, we lacked insight into the academic culture, missions, goals, and other factors that shape a school's expectations and interpretation of their policies. Without knowledge of these unwritten rules that sometimes shape decision-making, we had limited ability to detect differences in institutional priorities, such as placing higher value on scholarship productivity than teaching or other mission areas. We acknowledge that these variations between schools influence the requirements described in the promotion and tenure guidance documents. Although we used the Carnegie classifications depicted in Table 3 to approximate some of the differences in the mission of each school, we emphasize that our composite data represent the requirements from a large majority of US pharmacy schools. Additionally, we argue that written documents are the only guidance available to newly hired or prospective faculty to develop their initial plans for career advancement, so it is imperative that schools provide explicit guidance to all faculty rather than relying on history, precedence, and cultural norms to inform them. Similarly, the wording and language in the document, especially in the description of criteria, influenced how items were coded (eg, as required vs not required [credit given] criteria) and, in some cases, might not have been interpreted as intended. For some schools, we may have needed to include additional documents to ensure all promotion and tenure guidance documents were analyzed. Also, some schools may have updated their promotion and tenure guidance documents following our data collection and analysis.

\section{CONCLUSION}

Scholarship was a frequently acknowledged area of faculty responsibility in the promotion and tenure guidance documents of US schools and colleges of pharmacy; however, there was wide variability in the specific criteria that faculty had to meet to qualify for advancement. All but a few institutions included publications and grants as scholarship criteria in these documents, but other evidence of scholarship, such as presentations, SOTL, and honors and awards, were less frequently included. Many scholarship criteria, including publications, grants, contracts, and presentations, were recognized as potential but not required criteria for advancement. The lack of identifiable required criteria may make self-assessment difficult for faculty seeking advancement. Conversely, the inclusion potential rather than required criteria may offer faculty the flexibility to individually define how they have achieved excellence in scholarship. Our findings provide the most up-to-date, comprehensive qualitative content analysis of scholarship criteria within the promotion and tenure guidance documents of US pharmacy schools. These findings provide national benchmarks to assist these schools in creating or refining specific guidance documents for faculty advancement. 


\section{American Journal of Pharmaceutical Education 2021; 85 (3) Article 7983.}

\section{ACKNOWLEDGMENTS}

Drs. Snider, Hight, and Brunson were PharmD candidates at the University of Arkansas for Medical Sciences College of Pharmacy during the time the study was conducted. Funding for Dr. Snider's participation in the project was provided by the University of Arkansas for Medical Sciences College of Pharmacy Student Research Fellowship.

\section{REFERENCES}

1. Hardré PL, Kollmann SL. Motivational implications of faculty performance standards. Educ Manag Adm Leadersh. 2012;40(6): 724-751.

2. Klein KC, Kelling SE, Pais K, Lee CA, Bostwick JR. From clinical assistant to clinical associate professor: examination of a sample of promotion guidelines. Curr Pharm Teach Learn. 2019; 11(4):346-351.

3. Pfeiffenberger JA, Rhoney DH, Cutler SJ, et al. Perceptions of tenure and tenure reform in academic pharmacy. Am J Pharm Educ. 2014;78(4):75.

4. Register SJ, King KM. Promotion and tenure: application of scholarship of teaching and learning, and scholarship of engagement criteria to health professions education. Health Prof Educ. 2018;4(1): 39-47.

5. Boyer EL. Scholarship Reconsidered: Priorities of the Professoriate: Princeton, NJ: Carnegie Foundation for the Advancement of Teaching; 1990.

6. Austin Z, Gregory PAM. Promotion and tenure: clinical faculty at schools of pharmacy in Canada. Pharm Educ. 2006;6(4):267-274.

7. Glover ML, Armayor GM. An assessment of college of pharmacy promotion committees and criteria for promotion for pharmacy practice faculty. Pharm Educ. 2006;6(4):275-280.

8. Wolfgang AP, Gupchup GV, Plake KS. Relative importance of performance criteria in promotion and tenure decisions: perceptions of pharmacy faculty members. Am J Pharm Educ. 1995;59:342-347. 9. Nutescu EA, Engle JP, Bathija S, et al. Balance of academic responsibilities of clinical track pharmacy faculty in the United States: a survey of select American College of Clinical Pharmacy Practice and Research Network members. Pharmacotherapy. 2014; 34(12):1239-1249.

10. Prescott WA. Facilitating advancement of clinical-track pharmacy faculty members. Am J Pharm Educ. 2020;84(5):7910. 11. Bloom TJ, Schlesselman L. Publication rates for pharmaceutical sciences faculty members at non-research intensive US schools of pharmacy. Am J Pharm Educ. 2015;79(9):136.

12. Desselle SP, Andrews B, Lui J, Raja GL. The scholarly productivity and work environments of academic pharmacists. Res Social Adm Pharm. 2018;14(8):727-735.

13. Hight K, Payakachat N, Reinhardt M, Franks AM. A crosssectional analysis of self-reported scholarly publications among United States pharmacy practice faculty. Curr Pharm Teach Learn. 2020;12(8):918-925.

14. Weathers T, Unni E. Publication rates of social and administrative sciences pharmacy faculty in non-research intensive pharmacy schools. Am J Pharm Educ. 2017;82(3):6229.

15. Lubitz RM. Guidelines for promotion of clinician-educators. $J$ Gen Intern Med. 1997;12:71-78.

16. Accreditation Council for Pharmacy Education. Accreditation standards and key elements for the professional program in pharmacy leading to the doctor of pharmacy degree ("standards 2016"). https:// www.acpe-accredit.org/pdf/Standards2016FINAL.pdf. Accessed February 22, 2021.

17. American Association of Colleges of Pharmacy. Pharmacy faculty demographics and salaries. https://www.aacp.org/research/ pharmacy-faculty-demographics-and-salaries. Accessed February 22, 2021.

18. American Association of Colleges of Pharmacy. Student applications, enrollments, and degrees conferred. https:// www.aacp.org/research/student-applications-enrollments-anddegrees-conferred. Accessed February 22, 2021.

19. Pharmacy College Application Service. PharmD school directory. http://www.pharmcas.org/school-directory/\#/pharmd/ general-information. Accessed February 22, 2021.

20. American Association of Colleges of Pharmacy. Funded research grant institutional rankings. https://www.aacp.org/research/fundedresearch-grant-institutional-rankings. Accessed February 22, 2021. 21. Accreditation Council for Pharmacy Education. Programs by status. https://www.acpe-accredit.org/accredited-programs-by-status/. Accessed February 22, 2021.

22. National Association of Boards of Pharmacy. District composition. https://nabp.pharmacy/about/districts/. Accessed February 22, 2021.

23. The Carnegie Classification of Institutions of Higher Education. 2018 update public file. https://carnegieclassifications.iu.edu/ downloads.php. Accessed February 22, 2021.

24. Kleinheksel AJ, Rockich-Winston N, Tawfik H, Wyatt TR. Demystifying content analysis. Am J Pharm Educ. 2020;84(1):7113. 25. Cho JY, Lee E-H. Reducing confusion about grounded theory and qualitative content analysis: similarities and differences. Qual Rep. 2014;19(32):1-20.

26. Franks AM, Payakachat N. Positioning the scholarship of teaching and learning squarely on the center of the desk. Am J Pharm Educ. 2020:8046.

27. Fulford MJ, Early JL, Godwin DA, et al. Report of the 2017-2018 Academic Affairs Standing Committee. Am J Pharm Educ. 2018; 82(7):7163.

28. Gubbins PO. The scholarship of teaching and learning: an opportunity for clinical faculty members in academic pharmacy and other health professions to develop a program of scholarship.

International Journal for the Scholarship of Teaching and Learning. 2014;8(1):Article 3.

29. Medina M, Hammer D, Rose R, et al. Demonstrating excellence in pharmacy teaching through scholarship. Curr Pharm Teach Learn. 2011;3(4):255-259.

30. Schimanski LA, Alperin JP. The evaluation of scholarship in academic promotion and tenure processes: past, present, and future. F1000Res. 2018;7:1605.

31. American Association of Colleges of Pharmacy. Faculty Survey 2020 National Summary Report. https://www.aacp.org/sites/default/ files/2020-07/2020-faculty-national-summary-report_0.pdf.

Accessed February 22, 2021.

32. Robles JR, Youmans SL, Byrd DC, Polk RE. Perceived barriers to scholarship and research among pharmacy practice faculty: survey report from the AACP scholarship/research faculty development task force. Am J Pharm Educ. 2009;73(1):17.

33. Feder ME, Madara JL. Evidence-based appointment and promotion of academic faculty at the University of Chicago. Acad Med. 2008;83(1):85-95.

34. Balogun JA, Sloan PE, Germain M. Determinants of tenure in allied health and nursing education. $J$ Adv Nurs. 2006;56(5):532-541. 


\section{American Journal of Pharmaceutical Education 2021; 85 (3) Article 7983.}

35. Balogun JA, Sloan PE, Germain M. Core values and evaluation processes associated with academic tenure. Percept Mot Skills. 2007; 104(3 Pt 2):1107-1115.

36. Jhala K, Kim J, Chetlen A, Nickerson JP, Lewis PJ. The clinician-educator pathway in radiology: an analysis of institutional promotion criteria. J Am Coll Radiol. 2017;14(12):1588-1593.

37. Al-Zu'bi H. A study of relationship between organizational justice and job satisfaction. Int J Bus Perform Manag. 2010;5(12):102-109.

38. Bakhshi A, Kuldeep K, Ekta R. Organizational justice perceptions as predictor of job satisfaction and organizational commitment. Int J Bus Manag. 2009;4(9).

39. Bidarian $\mathrm{S}$, Jafari P. The relationship between organizational justice and organizational trust. Procedia Soc Behav Sci. 2012;47:1622-1626. 40. Colquitt JA, Conlon DE, Wesson MJ, Porter COLH, Ng KY. Justice at the millennium: a meta-analytic review of 25 years of organizational justice research. J Appl Psychol. 2001;86(3):425-445.
41. Francesconi M. Determinants and consequences of promotions in Britain. Oxf Bull Econ Stat. 2001;63(3):279-310.

42. García-Izquierdo AL, Moscoso S, Ramos-Villagrasa PJ.

Reactions to the fairness of promotion methods: procedural justice and job satisfaction. Int J Select Assess. 2012;20(4):394-403.

43. Komodromos M. Employees' perceptions of trust, fairness, and the management of change in three private universities in Cyprus. $J$ Hum Resour Manag Labor Stud. 2014;2(2):35-54.

44. Kondratuk TB, Hausdorf PA, Korabik K, Rosin HM. Linking career mobility with corporate loyalty: how does job change relate to organizational commitment? J Vocat Behav. 2004;65(2):332-349. 45. Ngan HFB, Tze-Ngai Vong L. Hospitality employees' unrealistic optimism in promotion perception: myth or reality? J Hum Resour Hosp Tour. 2019;18(2):172-193.

46. Stumpf SA, London M. Capturing rater policies in evaluating candidates for promotion. Acad Manage J. 1981;24(4):752-766. 